\title{
OVID AND THE IDEAL OF DOCTA PUELLA IN THE ROMAN EROTIC ELEGY ${ }^{1}$
}

\author{
Renata Cerqueira Barbosa ${ }^{2}$
}

\section{Resumo}

A Elegia Erótica Romana, é um tema que tem sido muito pesquisado por estudiosos de áreas relacionadas aos Estudos Clássicos. Contudo, as pesquisas geralmente dizem respeito à questão poética relacionada ao gênero elegíaco, ou tratam de autores elegíacos e suas composições. Neste gênero literário, principalmente no que se refere à poesia amorosa, os temas estão sempre relacionados às mulheres, amantes e seus comportamentos morais e ideais, o que desperta a curiosidade de outras mulheres para este tipo de leitura. O que esta poesia amorosa pode nos dizer sobre a educação das mulheres? Neste sentido, o objetivo do presente trabalho diz respeito à elegia erótica e a sua possibilidade de contribuição à educação das mulheres romanas.

\section{Palavras-chave}

Elegia Erótica, Ovídio, Educação Feminina.

\footnotetext{
${ }^{1}$ Translated by Bruno Sanches Mariante da Silva. This article is part of the postdoctoral research developed at Unicamp under the supervision of Professor Pedro Paulo A. Funari.

2 Associate Professor. State University of Londrina - Londrina, PR, Brasil. email: renata7barbosa@hotmail.com
} 


\begin{abstract}
The Roman Erotic Elegy is a topic that has been widely researched by scholars from areas related to Classical Studies. However, the researches usually concern on the poetic issue related to the elegiac genre, or they address to elegiac authors and their compositions. In this literary genre, especially when it comes to love poetry, the themes always relates to women, lovers and their moral behaviors and ideals, which arouses the curiosity of other women for this type of reading. What this love poetry can tell us about the education of women? In this sense, the objective of this study concerns to the erotic elegy and their possibility of contributing to the education of Roman women.
\end{abstract}

\title{
Keywords
}

Erotic Elegy, Ovid, Women's Education 
In complete contrast to old positions espoused by conservative men of the Roman elite (Carcopino, s/d) and the moral doctrine of the philosophers, like stoicism, for example, (Aubenque, 1981), are the unconventional ideas of Roman poets who sings love, from the late republic to the time of Augustus. Catullus, Tibullus, Propertius, Ovid (elegiac poets) and others express their views about women, female behavior and male-female relationships, which in many ways this is a reversal of traditional values. In thier poetry (probably fictitious) the beloved is the dominant party and her poet-lover, the humble servant who puts his love affair above the traditional Roman persecution of a military or political career (VEYNE, 1985); (FILIPE, 2002).

Part of this role reversal and unconventional attitude toward women found expression in poets who admired the docta puella (JAMES, 2003). With this rather vague term, poets denoted some appeal of young, attractive and clever woman, in the Greek educational triad: poetry, music and dance. In the eyes of the poet, the charms of her achievements, her taste for poetry, gift for music, dance ability and the intelligent conversation, classification above the birth and wealth, made up her supposed lack of traditional virtues.

The erotic Elegy is one of the most sophisticated forms of art throughout the history of literature; and, there are not many forms whose nature was more unknown. Two or three decades before the beginning of our era, young Roman poets, Propertius, Tibullus and, in the following generation, Ovid decided to sing in the first person, with their real names, loving episodes and relate these various episodes to one and same heroin, designated for a mythological name. Since then, readers have come to imagine the poets and their mistresses, Propertius and his Cynthia, Tibullus and his Delia, Ovid and his Corina (Veyne, 1985).

In Greece and Rome, the poetic genres were easily classified according to the metric on which they were written, the same way was the dance in accordance with the beat; these verses of love were made in elegiac pace ${ }^{3}$. According to Paul Veyne, "Roman elegy is a poetry that only requires the real to open an imperceptible gap between it and the poems...", in this case, between the author and the heroine; among his heroines, poets like Ovid, Propertius and Tibullus begged nights of love. In the principle was established that she, the heroine, distribute her favors as she pleased and to whom she wanted. This heroine, worshiped by noble poets, was not a noble lady but a woman of irregular life, and these poets would be ready for everything for their beloved, except marrying her.

${ }^{3}$ Metrical poems in couplets, this is, composed by hexameter alternating with pentameter. 
The poet and worshiper says "I" and speaks of himself with his real name of Propertius, Tibullus or Ovid: it is possible to find its traces in the poets of petrachist and romantic posterity. Interpreters have preferred not knowing too much what the elegiac love had as unedifying. It is possible that Propertius, or rather the Ego that it brings into play, suffer less with the jealousy than what he considers as fearsome the currents of passion, which in Antiquity was considered as a tragic fatality, bondage, an illustrious misfortune.

Sharon James (2003) states that the Erotic Elegy is a topic that has been much discussed, for two main reasons. First, it seems to express the emotion felt, but in an inconsistent and autobiographical form, although, at the same time, filled out with artifices. Second, readers, conditioned by romanticism, waiting sincerity, spontaneity and often biography from love poetry, have "stumbled" in the ironies and obscurity of the elegy, unable to reconcile its apparent emotion with its obvious artifice. The A.W. Allen's article (1950) "Sincerity and the Roman Elegists" (Apud James, 2003: 7) proved that it is impossible to derive a factual autobiography from an elegiac poet or even the real story of the love affair apparently described in his elegies. He demonstrated that, what might be called "the requirement of sincerity" - the expectation that the love of poetry expresses necessarily the genuine poet's emotion -, is not relevant to the Elegy, which is more concerned with poetry than with the autobiography or telling the factual events in any historical case of love affair. James, further, says that, since it has been trying to demonstrate the highly crafted nature of elegy, the requirement of sincerity hindered reaching it (James, 2003: 3).

This important work of Sharon James (2003: 7-8) do not want to suggest, she said, that every Roman elegiac poem must or should be interpreted from a female point of view, or that such perspective is dominant. First, there are many individual eulogies having little or nothing to do with women or heterosexual love, and, second, all Roman love elegy is overwhelmingly male in its sound perspectives. But the elegy, as implicitly as explicitly, identifies its favorite love object as a docta puella. A "learned girl" who can understand, appreciate and evaluate the literary strategies of a particular poem - and requires a gendered structure of partnered opposition, in which the lover and his puella engage themselves in its strategic tactic, in a complex choreography of regular opposition to the occasional union. In this partnered opposition, the poet-lover and the puella share important values and interests: they disregard conventional morality, ignore the politics, appreciate apprehended poetry, as well as the ability in music and dance; furthermore, the status as puella, instead of a respectable woman, makes her complicated relationship possible. Finally, as argued by the author, her profession and condition also rule the types of communication and persuasion directed at her. It is generally necessary, therefore, to examine the genre, many individual poems and topoi 
from the point of view of its members and female recipients, as well as their male speakers.

By analyzing the Roman elegiac poetry, James has done an approach based on the elegy of love. Her focus is on material and social realities, which means no discussion from a linguistic and psychoanalytic perspective. The author is interested in social position, in a combined way with the elegiac genre, which governs the puella's reading in generically way and the intense persuasion that directed her path. This approach is based on Roman historical practices, as well as biophysiological events, such as aging (which is devastating for the puella). The Elegy (not to mention ancient Roman culture), within its universe, establishes the existence of male and female, as both sexes and genders, this is, as bodies and as cultural concepts. Male and female take different and changing places in social and sexual elegiac relations. Its exact nature is indeed one of the major concerns of elegy - witness their inverted positions in the social hierarchy, designated by elegiac servitium amoris ("slavery of love") and terms that dominates (lover) - as it is the exact nature of their relations. The definitions of male and female, and their relationships, in constantly changing, with an organizational, structural and primary episodic principle, the elegy pretends to want its men and women are on the same side, so to speak, and, in fact, sometimes they are, but if they always were, there would be no elegy. Without the tension provided by its gendered structure of partnered opposition, the elegy would collapse. The fluidity of definitions and gender relations of the elegy vary from apparent reversal of the Roman pattern ideologies of gender to a fantasy realm, free of social requirements and customs, in which the lover and the beloved are practically one. These are intentional and conscious elements, constituents of this gender itself.

From the point of view of Veyne (1995: 17), the elegy treats women in an irregular life as heroines of Fable and the masters as feverish lovers. For the author, the elegy is not a demi-monde picture, once it does not describe anything in absolute and does not require its readers to think of the real society; it takes place in a fictional world where the heroines are also frivolous women, and reality is only evoked by flashes, inconsistent flashes. From a page to another, Delia, Cynthia or Corina, could be courtesans, adultery wives, free women; most often, it is not known what they are, and there are no worries about it: they are women with an "irregular" living; that is all.

Emily Hemelrijk (1999) follows the same line of interpretation. Freedom, behavior and free sexual accomplishments led to the assumption that women of the Roman love poetry are from demi-monde, but the social status as lovers of love poets is not clear and the possible relation with identifiable women remains doubtful. This irregularity is not a part of the lives of our poets and their alleged mistress, but a part of a system; it represents the law of the genre, plays a role that Paul Veyne calls as semiotic. It happened only subsequently, the reader could relate this fiction to the social spheres, a 
bit free from the time - if had the job of questioning himself -; moreover, this assignment adds nothing to the poem, at most the reader could amuse, seeing how the fiction had embellished reality.

Fiction waives reality and the shape belies the content: but sincerity can be mannered; being faithful to the text, this aesthetic imposed a undecidable balance between truth and theatrical performance (Veyne, 1995: 17).

Roman elegiacs felt a strong attraction to popular beliefs and the Roman antiquities. They made poems in which they also put ambiguities on these issues, where the dogmatic truth did not impose itself anymore to cultivated minds. However, they were even more attracted to another topic, the love, which is a subordinate and "questionable subject", when it is not the conjugal love and when the heroine is an irregular-life woman rather than a matron. The erotic elegy will keep the tradition of laughing at the popular belief, and imitating the text of the sacred laws and ex-votos. The elegiac "I" allows plus one humor: the poet attributes to himself the naive faith of the simple man. And the false ingenuity in matters of religion is traditional in the elegy; there was a consecrated joke about asking a lover one of these pious feats that was a pannychis, a night when one was completely deprived of sleep as a promise of mercy, and the poet himself was the god who the beloved would celebrate in bed. In short, the erotic elegy was a genre such that it could joke with sacred things, as well with the moral and the duty to make public career to serve the empire, without consequences from this joke (Veyne, 1995: 48).

According to Paul Veyne, the erotic elegy, "whether being a fun lie or turning reality into art object", it has a Hellenistic origin (James, 2003); (Too, 2001). The Romans knew, two centuries ago, that lovers wrote elegies about the home of their beloveds. It had been six or seven centuries that the Greeks sang love, in various metrics, in the first or third person; however for Veyne (1995: 48),

(...) knowing whether it had been omitted to sing too, in the first person, in elegiac pace and if they had led to the Romans the honor of being the first to do so, does have a limited interest and which answer is not: there have already been Hellenistic elegies where love was sung under the fiction of the ego, even if they were elegies that we wrongly call epigrams under the false pretense that they are too short (...).

An elegy consists of the ad libitum repetition of a full rhythmic element, the couplet, and this couplet was the true base of the unit of the elegy; among the Romans, it ordinarily offers a full meaning and its end coincides with the sentence. According to Veyne, the poet thrashes his couplets one by one; two or three couplets constitute a complete elegy, which the author calls epigram, and a single couplet may even be a complete poem. In typographical and anachronistic terms, it may be said that, for the ancient reader, each couplet was separated from the next by - as if it were - a blank, so

Revista Heródoto. Unifesp. Guarulhos, v. 01, n. 01. Março, 2016. pp. 321-340. 
that within the same elegiac piece, the discontinuities in the sequence of the ideas or the narration, shocked him less than us (Veyne, 1995: 68).

The Elegy was a fun poetry that composed a funny picture, although fantasistic, of the gallant men's lives; it was a poetry to make laugh; "the elegy is a flighty friend, a levis amica," says Ovid in his "Love's Remedy". However, it was customary to read it as a poem to cry. The torments of gallant life were taken at face value, while the elegy was fun in fact that was not to be taken seriously. It is a poetry without action, without intrigue that leads to an outcome or that sustains a tension, and that is why, in it the time has no reality at all. The before and the after do not exist, and neither the duration.

\section{Docta puella: The Elegy as educational practice}

Education transmitted to the west is an education oriented into young males. Thinking about Roman society, in its archaic rural-based phase, education sets on tradition (mos maiorum) and on reverence for the elderly and the Gods (pietas). The child, since birth, is subject to parental authority (patria potestas). This does not prevent the mother to be their first teacher and at the age of seven, the father becomes the educator. Later authors, such as Tacitus ${ }^{4}$ and Pliny-the-Younger ${ }^{5}$, confirm that it was usually the mother the first educator and the father was schoolmaster for Roman children and, in this process, they learned by heart the Law of Twelve Tables. For men, familial education ends, as a rule, at sixteen, wearing the manly toga. Then, a year after it, the young man starts his learning at forum with a family friend who is "remarkable" and then his military service, for which the he has been prepared by physical exercise, performed not with an oppressive purpose, as among the Greeks, but to achieve greater dexterity and strength.

Coming the Hellenism, this education changes with the formation of a HellenisticRoman culture. This fact can be seen on a large scale since the mid-second century BC due to Roman conquests, as in southern Italy as in the Eastern Mediterranean. Coming as prisoners of war, they easily became freedmen and could obtain the trust of Roman families. Among several known cases, we have the case of Polybius, to whom Scipio Emiliano asked to take care of his child's education because, for him, the knowledge of

\footnotetext{
${ }^{4}$ Tacitus. Dialogus de oratoribus. 28.4 "It is that once each child, born from chaste mother, was brought up not in the tiny room of a nursemaid, but in the guild and the mother's breast, whose main praise was to guard the house and serve the children".

${ }^{5}$ Pliny-the-Younger. Letters. VIII.14.6: "To each one served as a master the father; and, who had no father, the elders and revered stepped in for him".
} 
tradition (mos maiorum) would not be enough and wanted to ennoble it with the Greek sophia. In this context, there is the spread of Stoic philosophy, with Panaetius and the poets Lucilius and Terence. This group of critically influence in the future of Roman culture is called "Circle of Scipios". This learning with the Greeks extends abroad and the young Romans perfected themselves in philosophy and rhetoric in Athens and Rhodes (Pereira, 1989: 189).

In what concerns to the study of educated women in Roman society, it is impressively how scare women of apprenticeship are mentioned in our sources. Not even the matrona docta, a term used in the title of Emily Hemelrijk's book (1999), is found in Roman literature. It is a mixture of matron, classified as a married Roman woman, and docta puella, whose praises were sung in the poetry of love. Both terms are full with moral values. The matron is closely associated with traditional feminine values such as chastity, modesty, austerity, domesticity and devotion to her husband and children. In opposite, the docta puella from the love poetry from Augustan century was praised for its cultural achievements (in poetry, music and dance), but to the traditional Roman eyes her moral arouse suspicions; furthermore, the typical docta puella does not seems to have belonged to the elite. Of course, words and social practice do not always coincide, it is possible to detect the lack of a term to designate a respectable and educated woman, contrasting with the dubious reputation of docta puella, which indicates how ambivalent the roman feelings were with regard to women education (Hemelrijk, 1999).

In Roman society of the period there were no Christian monasteries in which girls could be taught and where women could retire themselves to devote their lives to the study and prayer (as it happened in the Middle Age), and as there was no other institution, customs or opportunities. Assuming that, there were women who chose another alternative to marriage and motherhood. It is perhaps understandable that we have hardly heard of any famous woman who has been "docta" in Roman society. However, as we shall see here, some elite women were highly qualified. So, what may have caused their obscurity in the world of education?

We must keep in mind that in Roman society the education and learning were typically male activities; knowledge of literary culture and the liberal arts were the hallmark of the "gentleman" of Roman elite. For educated men of elite, besides its practical value for a political career, it was a competitive field and a class differentiation instrument: the exhibition of education distinguished members of the elite from the members of other layers. Anyway, the study provided prestige, and education was fundamental to the social status and intellectual activities, while it did not contribute to important 
aristocratic activities such as politics and the practice of law. It belonged to leisure (otium) and, therefore, according to the old republican notion of secondary importance ${ }^{6}$ (Hemelrijk, 1999; Pereira, 1989).

During the Principate, there have had a change in attitude towards education: with peace and prosperity of Principate and the political power of the senatorial class declined, the intellectual activities gained esteem. It gave more room for activities that had little practical value or had been considered frivolous before, but members of the senatorial class always remained amateurs in literary intellectual activities. The pretense of amateurism regard to intellectual activities have had great importance to the attitude of the upper classes in relation to education and an entirely life dedicated to the study was unusual as it was among the members of the equestrian class and the decurions (although to a lesser extent).

This amateur ethos also affected elite women; on the one hand, it may have facilitated their participation, and on the other, a life dedicated to the study has been forbidden, once it was against the traditions of their class (and sex). Of course, the "leisure" of women differs fundamentally from the "leisure" of the men of their class: by being barred from political participation and military affairs, women of the upper class, whose lives have passed, or was expected to pass, in the privacy of their homes and families, had been condemned to a life of otium (which is not to say that they had nothing to do). Would this otium had allowed them to devote their leisure time to study, which could be comparable to otium honestum of their male pairs? No, there is no female counterpart of the respectful qualified doctus, which denotes a man of culture, degreed in liberal arts and with a civilized conduct. However, docta is sometimes used for a woman, but not always understood as a compliment, nevertheless, this does not imply that education was considered inappropriate for all women and that the class distinctions were of no consequences. The questions were more complex: wealth, family history and other factors related to the social position of elite women interacted with gender to determine the nature of their education (Hemerlrijk, 1999).

In adulthood, some upper-class women returned to the themes that had been taught during their youth and they continued their study of poetry, mathematics or philosophy. These educated women were not universally admired in Roman society, where the opinion on them varied from idealization of docta puella to dislike for the "intolerable" literate. Hemelrijk (1999) asks how these contradictory feelings can be

${ }^{6}$ More information about the concept of otium, consult M.H.R. Pereira (1989) who deals with the concept of Otium cum dignitate in Cicero. 
explained. Is there any progress in the judgment made on women educated in Roman society? According to the author, there were especially some goals in the education of elite women. The need of a "moral education", "the ideal of the educated motherhood", which can be expressed the ideals of women's education according to the literary sources, particularly the writings of moral philosophers and conservative senators from the imperial period, in which they highlight the beneficial effects of education on the women's moral and fulfilling their traditional role of wife and mother. In addition to these purposes, moralizing sources value "the social role of the upper-class matron" and the "education as a social status symbol."

Cynthia, the beloved of Propertius, is a good example. In addition to her beauty, she is praised as a skilled musician, who put her verses of love in music, and sung to the sound of her lyre, as an elegant dancer, a conservative spirited and - last but not least a woman with a good taste for poetry. Indeed, a poet herself able to judge and appreciate the poetry of her lover as his most demanding critic. However, these achievements, she shares with other puellae doctae as Corina of Ovid, are more similar to the charms of an educated courtesan than the erudition of a respectable upper-class woman, more so, their literary and musical achievements are portrayed as part of their erotic attraction. Sexually, she seems independent: although in some cases the husband is mentioned, the puella is portrayed as free to hold converse and even a (secret) love affair with her poet-lover.

\section{Literary Circles and the Disclosure}

The Latin literature was a matter of groups of friends or "circles": friends played an important role along the writing, reviewing and "publication" process of a literary work. Once a work was conceived and drafted, it means it has gone through several stages before being released to the public. Although it may, of course, vary widely, three phases can be distinguished. First, a copy was sent to a close friend who was invited to comment on the critical issue. Then, after the work being revised, a small group of friends would read it to test its reception; or copies could be sent to them for criticism. If, after one or more revisions, the author feels that he is sufficiently certain that this is the final version, then, presentation copies were sent to a larger group of friends, first the honored - if there was one. The work, in this phase, became public, or, using an anachronistic term, the work was "published". With more one copy, the work circulation was, then, out of the author's control: strangers to the author could copy it from a friend's text, from a copy in a bookstore or copy from a volume deposited in a

public library - but the last two were relatively late developments. Friends (and patrons) played an important role at this stage of "publication", considering that they

Revista Heródoto. Unifesp. Guarulhos, v. 01, n. 01. Março, 2016. pp. 321-340. 
could help to make the book known to a wider audience by recommending it to their friends and acquaintances or by organizing public recitations (Hemelrijk, 1999: 147).

The literary friendship seems to have been a male question: as far as we know, women have almost no place in it. Although few upper-class women had their poetry read, some acted as patron to poets; and there is only one case that may justify the assumption that a woman - under certain conditions - could participate in a literary circle: Sulpicia, the elegiac. It is theoretically possible that women have had their own literary circles for distribution of their own work, but there is no evidence of it. The rare access of women or total absence of any male literary friendships must have been an obstacle for their literary works: even if they had the necessary education, leisure and talent for writing poetry, they lacked the encouragement from literary friends who would read and criticize their work and published them. However, the work of all women who wrote poetry, that we know, must have had their work circulated in one way or another among educated men, or we would not have known of their existence. How did they achieve this? The most likely answer seems to be that, as the writers in other periods of history, they found the necessary contacts for the production and circulation of their work through their male relatives.

Taking Perilla as an example, we still know very little. Apparently, not even her real name has been preserved. She was the recipient of a poetry "letter" from Ovid's Tristia (3.7), sent to her from Tomis. The name "Perilla" may be a pseudonym: in Tristia Ovid does not mention the names of its recipients, for fear of embarrass them. According to Hemelrijk (1999: 149) this pseudonym was known: the love poet Ticida or Ticidas, a contemporary of Catullus, had used it, according to Apuleius, to hide his beloved Metella; and Ovid himself mentions Perilla as Metella's pseudonym who was celebrated by some poets, who he did not mention the names. He can have chosen it as a poetic tribute to those poets who belonged to the previous generation.

In his poem, Ovid addresses to her as an unmarried young woman, living with her mother: his letter, personified as a messenger that will find her, so he imagine her sitting with her mother (one female chastity topos) or among her books. Judging by the way he writes about her "modest fortune" and her personal library, she may have belonged to the same class (equestrian) that Ovid himself. He often refers to the close and cordial relationship between them, dating back to the "tender years of Perilla's childhood", in which he was to her "like a father to his daughter." From these observations, we assume that Perilla was his stepdaughter from a previous marriage of his third wife. There is much to say about this point of view: the long and cordial relationship from her youth onwards, the similarity in the way he describes his relationship with "Perilla" (like a father to his daughter) and perhaps, also, the fact that he portrays Perilla as a docta puella, but emphatically as chaste. If the name of Ovid's stepdaughter was Nerulla - which seems to have the Nerullinus nickname for his child 
- it would give an additional argument for his identification with "Perilla" because of the metric equivalence of the name. However, safety cannot be achieved; paternal attitude from Ovid towards Perilla may have been metaphorically significant or some other relationship, although, presumably, a family relationship cannot be overlooked (Hemelrijk, 1999: 150).

From Ovid's poem, "Perilla" emerges as a young talented woman, whose poetic gifts he encouraged. The most interesting part of the poem is the one in which he deals with her poetic collaboration before his banishment to Tomis. Ovid asks if she remained faithful to their common pursuit of composing verses and reminds her that he keeps helping her to guide her talent, from her early youth onwards. Here, we see a young woman working in her poetry, as well as male poets used to do when starting a poetic career: she is assiduously advised and encouraged by an older friend. Ovid recognizes her poetic talent, which, as he proudly pointed out, he had been the first to notice it: "I was the first to realize that in the early years of her childhood, when, as a father to his daughter, I was her guide and companion [duxque comesque]" 7 . The military terminology used by the poetic collaboration is common, and it shows that she was accepted into the male world of the literary friendship, in which an older poet, more experienced, is considered "a leader and a fellow soldier" used to guide the younger ones. As described by Ovid, he and Perilla read and criticized the poetry of each other, a cooperation in that, as the "senior" poet, he took the lead with firmness:

Dum licuit, tua saepe mihi, tibi nostra legebam; saepe tui iudex, saepe magister eram: aut ego praebebam factis modo versibus aures, / aut ubi cesares, causa ruboris eram. (Ovid. Trist.3.7.23-6.)

In this poem, we can find a young female participant, as a junior partner in the male world of literary friendship. Seeing that, outside this poem nothing is known about Perilla, she remains shadowy. If she is identified as Ovid's stepdaughter, she lived her adult life in anonymity, as most Roman women: she got married and had children. Alternatively, she may have lived as an unmarried girl, a promising poet, as in the verse quoted, stimulated by a senior poet, with a poetry composed for the purpose of publication. If she continued writing during her married life and her poems were finally published, we cannot say; and neither there is mention of them in our sources.

Information about Perilla is scarce, however, about Sulpicia we find more references. Sulpicia is the only female writer of Latin poetry whose work has been preserved, at least in part. Six short elegies of hers come to us by the corpus Tibullianum. Sulpicia was

${ }^{7}$ Ovid. Tristia, 3.7.17-18: "primus id aspexi teneris in virginis annis, / utque pater natae duxque comesque fui"”. 
the daughter of Servius Sulpicius Rufus, man of politics. Her mother seems to have been Valeria, sister of Messala, who, after her brother-in-law's death of, played a leading role in education and training of Sulpicia (Filipe, 2002). As the poetic production of the Augustan period turned around literary circles, like the one of Maecenas, in which Horace, Virgil and Propertius took part, among others. Sulpicia was part of the circle of Marcus Valerius Messalla Corvinus, along with Tibullus, Lygdamus and subsequently Ovid (Paratore, 1983). We can find the poetic productions of this group brought together in what we would call today a "songbook", known as Corpus Tibullianum, because Tibullus is the most renowned poet (Parker, 1994). The fact of having spent her childhood in a non-conventional means - taking into account what we know of the formation of a Roman young - may have contributed to arouse her sense of independence and some freedom in poetry, as well.

Sulpicia's poetry uses her own name and identity; gives her beloved a name associated with poetry; evades family involvement; wills isolation with her lover; seeks to be known publicly for loving him. Distinguished by elegance, erudition and high-class, the common prostitute is her rival; resents the infidelity of her beloved; demands proofs that he loves her in return for her devotion; and identifies poetry as a means of sexual persuasion. Where she identifies her status as an elite woman, in contrast with a scortum, she invokes disdain meant for the male lover and poet for a lower-class rival. Considering that Sulpicia is an elite woman writing a love elegy, her speech did not need to offer verses in place of money; therefore, in her case, poetry is free from the elegiac impasse. What Sulpicia's elegy offers is, mainly, a means of exploring female sexuality and express female sexual anxiety and insecurity (James, 2003: 220). Thus, this kind of poetry that women like, and that looks like women, allows a female voice to talk about their own erotic concerns. Significantly, as Hallett (1989: 71) points out, Sulpicia seems "to portray herself as having much in common with the celebrated mistress of her male elegiac colleagues". The Elegy and the docta puella, allow Sulpicia to try herself, in designing of Hallett, both as "equal" and as "other". Catullus' Lesbia and Horace's numerous women do not offer such opportunity. Sulpicia's sex and her social status, however, cause the shortening of the trajectory of her poetic narrative. The usual plots and arguments of elegy are not available to her speech, therefore, her poems are few and short, although, graceful and complete. She offers a significant poetic reminder of, as much, the receiving of the female sex in the loving elegy, as the unspoken social circumstances that dictate and predetermine the resolutions of the elegiac love (James: 2003, 220).

The examples of Perilla and Sulpicia show two successive steps in the writing and publishing process of a literary work: poetic collaboration (Perilla) and "publication" (Sulpicia). However, the participation of women in the world of literary friendship must have been rare. To our knowledge, the Roman literary circles were usually 
composed exclusively of men; no female poet is mentioned among literary pupils of Mecenas or any other literary patron. The military metaphor (comesque duxque) used for poetic cooperation between a senior poet and a younger one - in this case applied between Ovid and Perilla - clearly reflects the fact that the world of literary production was exclusively male. However, as we have seen, the talented women can occasionally have had access to literary circles and to the publishing channels; at least, when they were supported by male relatives, who were poets or literary clients (Hemelrijk, 1999: 153).

Certainly, two female poets, all writing about the same period (from the middle of the first century $\mathrm{BC}$ to early first century $\mathrm{AD}$ ), do not prove that the talented women could not participate in a literary circle or publish their poetry unless they were encouraged by male relatives. It's possible that at the end of the first and second centuries AD, when writing poetry was the trend among men and, as it seems, the women from the upper class - the access to literary circles has become more open to women. However, the female poets discussed here sustain the view that the support provided by male relatives was crucial.

As the literary contacts and incentives were essential, the limited access of women to literary circles severely restricted the number of women who were able to circulate and publish their work. Although this does not hold back the efforts in poetry, in the privacy of their homes, their relative isolation of the literary life it happened almost impossible for them to make their poetry known by their contemporaries and, thus, eventually, to us. The few cases that form an exception have to be considered.

\section{Ovid and the Elegy Erotic}

Scholars are divided on the purpose, the effect and the success of the way Ovid deals with the poetic genre, although it is probably safe to say that many, if not the most, readers find him irreverent, often shocking and inappropriate. Therefore, the result of his work is judged inferior to his contemporaries and predecessors' (see Boyd, 1997: 112), demonstrating be missing the moral, aesthetic, taste and character (James, 2003: 155). The Ars Amatoria and Amores have been criticized for mocking, satirizing, parodying or making fun of the works of Propertius, Tibullus and Catullus; as a result, Ovid was criticized as an inferior poet, and as personally and morally defective. According to Sheron James's opinion, such criticism ignores the "self-parodic" and hilarious elements of the elegy, as a whole. Ovid failed even more asking why satirizing a genre is necessarily a bad thing, or why the literary satire should indicate understanding or comprehension of the inappropriate gender of an author. This kind 
of criticism rests on the wrong and romantic interpretation of the elegy and the demand of sincerity, reasons why the Elegy can not be understood as real facts reported, the events are always fictitious.

In James' view (2003: 155), Ovid knew very well what he was doing in his works Amores and Ars Amatoria. It's worth noting that the persistent work in the elegiac genre for twenty-seven years, revising and republishing Amores, adding the book III to Ars and including Remedia Amoris to its corpus and, finally, devoting so much time of his life to the elegy, it was not possible argue that he did not know what he was doing. James takes as a fact, not just the fact that Ovid considers each poem in Amores appropriate and necessary for his poetic program, but also that their placement is deliberate (particularly the initial location of 1.7 and 1.14 and relatively central position 2.13-: - 14) designed to show the specific issues and problems of elegy.

Many authors interpret issues aroused by the elegy of Ovid as an offense against women. Why does he find room in the elegy for poems about his sudden baldness (1.14) and abortion (2,13-14), the constant priapic condition of the poet lover (2.4) or his failure (3.7), his willingness to be, at the same time, both exploitative and openly abusive with his mistress and his slaves $(2.2$ to $312,7-8)$ and so on? Why does the elegy of Ovid openly expresses so much insincerity and so little passion and elegiac suffering? Why does he continue, so intently, focused on the insincerity, deception, infidelity and revulsion against women?

To James (2003: 157) Ovid does not add hypocrisy, exploitation and pretension in the Roman love elegy - he puts it naked. As Mack (1988: 62) points out, "Ovid offers us glimmers of real life behind the elegiac conventions. In real life, actions have consequences. Part of the Ovid's analysis of the conventions involves bringing some of these consequences to the fictional world of elegy. "

The disturbing and disorienting effect that Amores and Ars have over many readers are deliberate and strategic and should be considered as a shock effect designed to make readers rethink the elegy of love. The primary charge against Ovid's love elegies is that they are too focused on sex, but relatively little about love. That is to say that his speech does not seem to be actually about love with a woman, but rather a search of adventure. According to James, these sexual complaints could very well be fixed, as it follows: in Amores, Ovid pays attention not to the heart, as Propertius and Tibullus are thought to do, but to the body. It's worth noting that the body focused on Amores is the puella's. In 1.141 the hair falls out; in 2,13-14 she has an abortion. This led all the readers to conclude that both Ovid as its homonym speech are more interested in the body than the mind and the heart. Indeed, the poet-lover, Ovid, speaks about loving the body of a puella rather than her personality. However, the author argues that this aspect of Ovid's elegy - its emphasis on carnality, so to speak - reveals the same basis of 
all elegiac base. It's in the male sexual attraction to feminine beauty, where is, simultaneously, the generator agent of the sexual desire of lover-poet, the physical target of his anger when he realizes that he cannot control the puella. The focused exhibition of Ovid on the connections between female beauty and male sexual aggression reveals, retrospectively, the same phenomena in Propertius and Tibullus (James, 2003: 157-158).

\section{Conclusion.}

Issues relating to women's education in classical antiquity is a subject with many gaps to be filled. The works that we have access always deal with the men's education, usually referring to the public and political sphere; while women received an education aimed at their expected role in society; this is, to be wife and mother. In this manner, Roman erotic elegy stands out, whereas it was accessible to women, with issues relating to them, which dealt with them.

In this universe of reading and readers, many women felt seduced to write their own stories, poetry and issues related to their daily lives. However, due to the fact of history, especially in antiquity, be written by men, these stories and writings were not accessible to us. We can rely only on few sources and reports coming from women. In this context, docta puella is a character who flees from the respectable Roman matron standards, due, precisely, the access she had to the current male world and mainly for her artistic and cultural training.

A way found to deal with this set of themes, in the article exposed here, was to demonstrate that through Sulpicia's poetry and the correspondence between Ovid and Perilla, women had rather an active voice, but they needed the male presence for propagation, which made them dependent on their circles of poets and writers friends. Nevertheless, the fact of being part of the literary circles have confirmed their active participation in the written culture of Roman society.

From the end of the Republic onwards, the number of educated women increased, causing mixed feelings in the society of the period. Conservatives senators, such as Cicero and Sallust, defended the dignity and traditional virtues to their wives; Sallust defended dignity and traditional virtues for women of his class, and this topic clashed with the life of luxury and pleasure associated with Greek culture. Therefore, they ignored the Greek learning in women they respected. They spoke of women education, especially their ability in singing and dancing, only when they wanted to defame female opponents. This does not mean that they were opposed to women's education in private life, but, in their writings, they put traditional morality in first place. As

Revista Heródoto. Unifesp. Guarulhos, v. 01, n. 01. Março, 2016. pp. 321-340. 
opposed to the ideal of matron, in elite, the poets of love from the late republic and Augustan period, as Propertius and Ovid, idealized the docta puella, a young woman of indefinite social status and loose sexual morality, who was an expert in Greek educational triad, poetry, music and dance. Thus, we see that the opposing views coexisted, albeit in different groups of society: the poets of love were young knights who opposed the strict prescribed moral standards of members of the elite as revived in the moral legislation of Augustus.

In a later period of the Principate, the image of the literate and educated woman has changed. The ideal of docta puella had been stripped of its sexual license connotation and had incorporated the ideals of the married life. In the letters of Pliny for and about his wife, the influence of the love poetry from Augustus period are seen: in addition to complement her traditional virtues, Pliny publicly confesses his love and even his passion for his wife in an unusual way (and maybe even unthinkable) among men of his class, before the empire. In his letters to Calpurnia, he adopts the literary conventions and images of love poetry. Pliny's letters demonstrate some "domestication" of the ideal of docta puella for her incorporation into married life. Thus, the sophisticated and exciting docta puella from the love poetry has become the welleducated and devoted wife.

Regarding to the erotic elegy of Ovid, this has roused many critical debates and scholars on the theme. Some authors have interpreted the love poetry of Ovid, as criticism and depreciation of female image, some not, who defend the idea that Ovid "touched the wound" of Roman family and society when proposing feminine activities that enchanted men. Many issues can be further raised in this perspective and several works have appeared on the subject, as the cited works of Emily A. Hemelrijk and Sharon James that deal with literate and educated matrons of Roman society and the image of the puella in the elegiac poetry. The work of Yun Lee Too also brings great contribution with information on education in classical antiquity, escaping from traditional and generalizing studies of the topic. Works like these related to female themes contribute to the possibility of new researches that address women and their public participation in Roman society.

\section{Bibliographic References}

ALFÖLDY, Géza. A História Social de Roma. Lisboa: Editorial Presença, 1984.

AUBENQUE, P. As filosofias Helenísticas: Estoicismo, Epicurismo, Cericismo. In: CHÂTELET, François (org). In: História da Filosofia: ideias, doutrinas. Vol. 1. A Filosofia Pagã .Rio de Janeiro: Zahar, 1981. p. 167-198.

Revista Heródoto. Unifesp. Guarulhos, v. 01, n. 01. Março, 2016. pp. 321-340. 
BERNAL, M. A imagem da Grécia Antiga como uma ferramenta para o colonialismo e para a hegemonia europeia. In: FUNARI, P. P. A. Repensando o Mundo Antigo. Textos Didáticos. Campinas: Unicamp, 2005.

BOYD, B. W. Ovid's Literary Loves: Influence and Innovation in Ovid's Amores. Ann Arbor, 1997.

BUTTLER, Judith. Problemas de Gênero: Feminismo e subversão da identidade. Rio de Janeiro: civilização Brasileira, 2003.

CARCOPINO, J. A Vida quotidiana em Roma no apogeu do Império. Lisboa: Livros do Brasil, s/d

CHERVEL, A.; COMPÈRE, M-M. As humanidades no ensino. In: Educação e pesquisa. São Paulo, v. 25, n. 2, p. 149-170, jul/dez, 1999.

CÍCERO. Da República. Tradução de Amador Cisneiros. São Paulo: Atena Editora, s/d.

CURRIE, H. MacL., The Poems of Sulpicia, ANRW 2,30.3 (1983) 1753.

DE CERTEAU, Michel. A operação Historiográfica. In: A Escrita da História. Rio de Janeiro: Forense Universitária, 2000, pp. 65-119.

DIXON, S. The Roman Mother. London: Routledge, 1990.

FILIPE, R. T. As elegias de Sulpícia: Uma voz feminina num mundo de homens. Ágora: Estudos Clássicos em Debate 4. 2002. P. 57-78.

FINLEY, M. I. As Silenciosas Mulheres de Roma. In: Aspectos da Antiguidade. São Paulo: Martins Fontes, 1991. p. 149-164.

. Uso e Abuso da História. São Paulo: Martins Fontes, 1989.

FUNARI, Pedro P. A. Romanas por elas mesmas. In: Cadernos Pagu. 1995. pp. 179200.

HALLET, J. Woman as Same and Other in the Classical Roman Elite. Helios. 1989, 16.

HEMELRIJK, Emily A. Matrona Docta: Educated women in the Roman élite from Cornelia to Julia Domna. London and New York: Routledge, 1999.

HORÁCIO; OVÍDIO. Sátiras/Fastos. Traduções de Antonio Luís Seabra e Antonio Feliciano de Castilho. Rio de Janeiro: W. M. Jackson Inc. Editores, 1949. v. 4.

JAMES, Sharon L. Learned Girls and Male Persuasion: Gender and Reading in Roman Love Elegy. Los Angeles: University of California Press, 2003. 
LEITE, L. R. Difusão e recepção das obras literárias em Roma. In: LEITE, L. R.; SILVA, G. V. (Orgs.) As múltiplas faces do discurso em Roma: textos, inscrições, imagens. Vitória: EDUFES, 2013. P. 83-99.

MACK, S. Ovid. New York: Yale University Press, 1988.

MACROBIUS. The Saturnália. Columbia University Press, 1969.

NOVAK, M. G.; NERI, M. L. Poesia lírica Latina. São Paulo: Martins Fontes, 1992.

OVIDE. L'Art d'Aimer. Tradução de Henry Bornecque. Paris: Les Belles Lettres, 1994.

Oeuvres complètes. Tradução de Th. Burrette et al. Paris: C.L.F. Panckoucke, $1834 / 1837$.

OVÍDIO. Ars Amatoria. Edição Bilíngue. Trad. Natália Correia e David MourãoFerreira. São Paulo: Ars Poética, 1997.

As Metamorfoses. Tradução de Antonio de Feliciano de Castilho. Rio de Janeiro: Organização Simões, 1959.

Las Heroidas. Tradução em verso de Diego de Mexía. Buenos Aires: Coleção Austral, 1950.

. Obras: Os Fastos, Os Amores e Arte de Amar. Traduções de Antonio Feliciano de Castilho. São Paulo: Edições Cultura, 1943.

Os Remédios do amor: os cosméticos para o rosto da mulher. Tradução de Antônio da Silveira Mendonça. São Paulo: Nova Alexandrina, 1994.

. Tristium. Edição bilíngüe. Tradução de Augusto Velloso. Rio de Janeiro: Organização Simões, 1952.

PARATORE, E. História da literatura Latina. Lisboa: Fundação Calouste Gulbenkian, 1983.

PARKER, H. Sulpicia, the Auctor de Sulpicia, and the authorship of 3.9 and 3.11 of the Corpus Tibullianum, Helios. 1994, 21.1: 39-62.

PEREIRA, M. H.R. Estudos de História da Cultura Clássica II. Lisboa: Fundação Calouste Gulbenkian, 1989.

PETRÔNIO. Satyricon. Tradução de Paulo Leminski. São Paulo: Brasiliense, 1985.

PLINY THE YOUNGER. Letters. Trad. William Melmoth. Londres: W. Heinemann, 1958. 
RODRIGUES, N. S. Agripina e as Outras: Redes femininas de poder nas cortes de Calígula, Cláudio e Nero. Gerión. V. 26, n. 1, p. 281-295, 2008.

SÊNECA. Consolação a Hélvia. In: ___ Cartas Consolatórias. Tradução de Cleonice Furtado Mendonça Van Raji. Campinas: Pontes, 1992.

SUETÔNIO. As Vidas dos Doze Césares. Trad. Sady-Garibaldi. São Paulo: Atena, 1959.

SUETÔNIO. A vida dos doze Césares. Tradução de Pietro Nassetti. São Paulo: Martin Claret, 2006.

TÁCITO. Diálogo dos Oradores. Tradução de Agostinho Santos. Lisboa: Livros Horizonte, 1974

TÁCITO. Diálogo sobre los oradores. Tradução de Nicolás Gelorminni. Buenos Aires: Losada, 2009.

TOO, Yun Lee. Education in Greek and Roman Antiquity. Boston: Brill, 2001.

VEYNE, Paul. A Elegia Erótica Romana. O amor, a poesia e o ocidente. São Paulo: Brasiliense, 1995. 